\title{
A Quantity Analysis on Optimizing Corporation's Capital Structure
}

\author{
ZHAO Xin-gang \\ College of Business \\ North China Electric Power University \\ Beijing, China
}

\author{
YAN Yao-min \\ Torch High Technology Industry Development Center \\ MOST .P.R.China \\ Beijing, China
}

\begin{abstract}
How to choose the capital structure has been the probe question of the economy circle in China. This paper has a quantity analysis on corporation's capital structure and puts forward a method to confirm the best capital structure about financing decision in order to help the business policy maker.
\end{abstract}

\section{Keywords- capital structure; capital cost; financial risk}

\section{INTRODUCTION}

Capital structure comes to being when an enterprise makes financing activities to raise capital in various ways. And the different combinations of funding ways decide its capital structure and changes. Optimal capital structure refers to enterprise gets lowest weighted average cost of capital while its value achieves its maximum in certain conditions. In theory, there is an optimal capital structure, at which point, the enterprise can reach its maximum value at the lowest cost of capital. This structure is neither a zero liability, nor $100 \%$ liability, but of appropriate structure proportion, which ensures the achievement of corporate financial management objectives to maximize the enterprise value. Therefore, at the financing time, it is necessary to measure the risk of funding and to confirm the optimal capital structure.

\section{THE MEASURE OF THE MERITS OF A CAPITAL STRUCTURE}

One of the important factors in the decision-making of corporate financing is to decide the proportions of all kinds of funding sources taking up in the aggregate capital, that is, to determine the capital structure. In general, it is unwise for the enterprise to fund entirely by equity capital as the return required by the remuneration could only be distributed from after-tax profits. It can not go as the interest of debt which can be taken away from the pre-tax income as a cost, thus playing the role of non-tax deductible. However, too many funds rising rely on liabilities would enable the company to bear the financial burden of debt up to due, which would likely make the company fall into the financial crisis, thereby increase the risk. Whether there is a certain optimal capital structure? How to measure the merits of the capital structure? To discuss these issues purely from the qualitative perspective is far from sufficient. We should take quantitative analysis on the advantages and disadvantages of the capital structure.

\section{A. Stock price is the measure of the merits of capital structure}

The goal of modern enterprise financial management is to maximize shareholder's wealth or the corporate value. In the modern economic market, the value of the business can only be shown by price when entering the market, specifically, that's the cash investors obtained when selling the enterprise. In reality, this data is not easy to obtain. But to the listed Inc., its stock price represents the value of the enterprise. Therefore the maximization of the stock becomes the aim of financial management for Co., Ltd. Here we take List Company for example to have a research on capital structure and its principle can also apply further types of enterprises in economic market.

Stock prices are affected both by the external economic environment and enterprise self-management. Looking form the controllable factors of enterprises themselves, the stock prices depends on the profitability and risks of the business. Usually, the stock price changes synchronically with that of the profitability, and exactly the reverse from the risk. Thus the measure on the capital structure of enterprises should include two aspects: the profitability of the business and risks.

\section{B. The methods to determine the profitability and risks of the business}

As an aggregate target, net income (NI) could not reflect the relationship between input and output, while the total return on capital reflects profitability of all the funds (including equity capital and borrowed funds). The shareholders are the owners of the company and their investment return is the main basis in financial decisionmaking. So we select the return on equity (ROE) as a standard to determine the profitability of the business.

$$
R O E=\frac{N I}{E}
$$

Of which: E for the owner's equity capital.

The result of any economic activity of an Enterprise is of uncertainty, which can bring out of expected earnings as well as losses beyond expectation. This uncertainty is just the risk. Here we select three indicators to measure the risk of fund rising: the standard deviation $\sigma$, coefficient $\beta$ and coefficient of financial leverage

Sponsor: North China Electric Power University 
To select the standard deviation $\sigma$ as a measurement of risk in financing, there are two considerations:

1) According to probability theory, $\sigma$ can reflect the discrete level of the possible outcome with the expectations. The introduction of $\sigma$ to the measurement of financing risk, it can indicate the fluctuations of ROE in different capital structure.

$$
\sigma(R O E)=\sqrt{\sum_{i=1}^{n} P_{i}\left[R O E_{i}-E(R O E)\right]^{2}}
$$

Of which: $P_{i}$ is the probability of emergence the i result, $E(R O E)$ is expectations for ROE.

2) When the random variables in line with the normal distribution, $\sigma$ will affect the confidence probability of a specific confidence interval. What is mostly concerned in finance is the loss probability, that is, the probability of equity return less than 0 , which can be expressed as:

$$
P(X)=\int_{-\infty}^{x} p(\mu) d \mu, \text { 且 } X=\frac{0-\mu}{\sigma}
$$

Of which: $p(\mu)$ is a parameter $\left(\mu, \sigma^{2}\right)$ of density function of normal distribution.

When measuring the financing risk, $P(X)$ may indicate the probability of loss in different capital structure, and can also be expressed as follows:

$$
X=\frac{0-\mu}{\sigma}=\frac{0-E(R O E)}{\sigma(R O E)}=\frac{-E(R O E)}{\sigma(R O E)}
$$

Also, in accordance with the Capital Asset Pricing Model (CAPM), factor $\beta$ can reflect the changes of individual stock relative to the market average risk For example, when the coefficient $\beta$ is 2 , it represents the risk of certain shares is 2-fold of the average risk of stock market, the namely: if the average market rate of return rise 1 percent, the rate of return of the stock will rise 2 percent . Now we introduce the coefficient $\beta$ into the measurement on the risk of funding decision-making, it will be:

$$
\beta=\frac{\operatorname{COV}\left(R O E, R_{M}\right)}{\sigma^{2}\left(R_{M}\right)}
$$

Of which: $R_{M}$ stands for the average ratio of equity return under the average market risk.

Since debt interest rates do not vary with the change of NT (EBIT), if the enterprise pre-tax income grows, every dollar of pre-tax income affords the interest of NT will become relatively less, so that it brings greater net profit. In the financial management of such impact of liabilities to the earnings of shareholders is called financial leverage, and the ratio of the net profit change rate and the pre-tax income change rate is known as the coefficient of financial leverage (DFL), calculated as follows:
$D F L=\frac{\Delta N I / N I}{\Delta E B I T / E B I T}=\frac{\frac{\Delta E B I T(1-T)}{(E B I T-r \cdot D)(1-T)}}{\frac{\Delta E B I T}{E B I T}}=\frac{E B I T}{E B I T-r \cdot D}$

Of which: $\mathrm{D}$ is the amount of liabilities, $\mathrm{r}$ is the interest rate for the debt, and $\mathrm{T}$ is tax rate.

Coefficient of financial leverage can express role of financial leverage and the property risk in financing decisionmaking. The greater the coefficient, the greater role of the financial leverage plays, then the greater risk of the property.

\section{THE QUANTITATIVE ANALYSIS ON OPTIMIZING THE CAPITAL STRUCTURE}

Supposing the total assets (A) of an enterprise are 10000 Yuan, tax rate (T) is $40 \%$, debt interest rate (r) is $10 \%$, with the

\begin{tabular}{|c|c|c|c|c|c|c|}
\hline \multicolumn{2}{|c|}{$\begin{array}{c}\text { Condition of Market } \\
\text { management }\end{array}$} & $\begin{array}{l}\text { Very } \\
\text { poor }\end{array}$ & Poor & General & Good & $\begin{array}{l}\text { Very } \\
\text { good }\end{array}$ \\
\hline \multicolumn{2}{|c|}{$R_{M}(\%)$} & $\begin{array}{l}- \\
10.0\end{array}$ & 0.0 & 10.0 & 20.0 & 30.0 \\
\hline \multicolumn{2}{|l|}{ EBIT(元) } & $-\overline{1200}$ & 400 & 2000 & 3600 & 5200 \\
\hline \multicolumn{2}{|l|}{ ROA(\%) } & -12.0 & 4.0 & 20.0 & 36.0 & 52.0 \\
\hline \multirow{2}{*}{$D / A=0$} & $\mathrm{NI}$ & -720 & 240 & 1200 & 2160 & 3120 \\
\hline & ROE(\%) & -7.2 & 2.4 & 12.0 & 21.6 & 31.2 \\
\hline \multirow[t]{2}{*}{$D / A=0.5$} & $\mathrm{NI}$ & $\begin{array}{l}- \\
1020\end{array}$ & -60 & 900 & 1860 & 2820 \\
\hline & ROE(\%) & -20.4 & -1.2 & 18.0 & 37.2 & 56.4 \\
\hline \multirow[t]{2}{*}{$D / A=0.8$} & $\mathrm{NI}$ & $\begin{array}{l}- \\
1200\end{array}$ & -240 & 720 & 1680 & 2640 \\
\hline & ROE(\%) & -60.0 & 12.0 & 36.0 & 84.0 & 132.0 \\
\hline
\end{tabular}
assumption that the probability of the results in the market and enterprises operating is equal.

Table 1

In the table, ROA stands for the return on total assets (EBIT), D / A stands for the asset-liability ratio.

A. the relationship between Corporate profits and the capital structure

The relationship between the Return on equity (ROE) and asset-liability ratio (D / A) can derive form the formula (1):

$$
R O E=\frac{N I}{E}=\frac{(E B I T-r \cdot D)(1-T)}{A-D}=\frac{(R O A-r \cdot D / A)(1-T)}{1-D / A}
$$

Of formula (7) for partial derivatives, are:

$$
\frac{\partial R O E}{\partial(D / A)}=\frac{1-T}{(1-D / A)^{2}}(R O A-r)
$$

The up formula declares that when ROA $<\mathrm{r}$, that is the return on total assets (EBIT) is less than the loan interest rate, ROE is the reduction function of D / A, which means the higher the debt ratio, the lower equity return ratio and thus liability fund-raising is a disadvantage; When $\mathrm{ROA}=\mathrm{r}$, ROE has no business with $\mathrm{D} / \mathrm{A}$; only when $\mathrm{ROA}>\mathrm{r}$, the corporate operating under debt is beneficial. Let's express the relationship between ROE, ROA and D / A using the data of Table 1 as follows. 


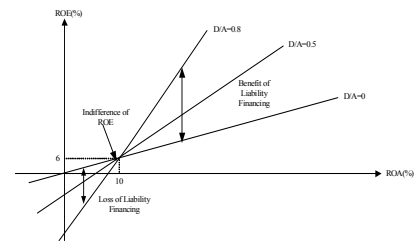

Figure 1. the relationship among ROE、ROA and D/A

Figure 1: straight lines of ROE-ROA relation of different capital structure meet at one point $(\mathrm{ROA}=\mathrm{r})$. At this point, the ROEs of different capital structures are at the same value; In ROA-axis, the region that is higher than this point goes like this: the higher the fund-raising ratio is, the more potential gains of funding liabilities; and where it is lower than this point, the higher the ratio of liabilities of fund-raising may brought about greater loss of funding liabilities.

\section{$B$. The relationship between the enterprise risk and capital structure}

Based on the data of Table 1, we calculate the risk indicator of different capital structures under this case, as shown in table 2.

Table 2
\begin{tabular}{|l|l|l|l|}
\hline \multirow{2}{*}{\multicolumn{1}{|c|}{ Enterprise Risk }} & \multicolumn{3}{|l|}{ Asset-liability ratio $\quad($ D/A $)$} \\
\cline { 2 - 5 } & 0 & 0.2 & 0.8 \\
\hline$\sigma(R O E)(\%)$ & 13.6 & 17.0 & 67.9 \\
\hline B Coefficient & 0.96 & 1.14 & 4.80 \\
\hline DFL of general operating condition & 1.00 & $10 / 9 \approx 1.11$ & $5 / 3 \approx 1.67$ \\
\hline
\end{tabular}

1) Standard deviation $\sigma(R O E)$ and asset-liability ratio and $D / A$

Based on formula (7) and (2), we get,

$$
\sigma(R O E)=\frac{1-T}{1-D / A} \sigma(R O A)
$$

In formula (9), calculate the partial derivativesors for $D$ / $A$ and $\sigma(R O A)$ respectively, we get,

$$
\begin{aligned}
& \frac{\partial[\sigma(R O E)]}{\partial(D / A)}=\frac{1-T}{(1-D / A)^{2}} \sigma(R O A)>0 \\
& \frac{\partial[\sigma(R O E)]}{\partial[\sigma(R O A)]}=\frac{1-T}{1-D / A}>0
\end{aligned}
$$

From formula (10) and formula (11) we can get that the standard deviation of return on equity $\sigma(R O E)$ is not only the increasing function of asset-liability ratio, but also the increasing function of total assets of the standard deviation of return $\sigma(R O A)$. It indicates that the higher the debt ratio, the greater the business risk, while the more stable of return on total assets, the smaller risk the enterprise takes. Therefore, as to an enterprise with comparative stable return on total assets, the debt ratio could be higher in order to maintain a certain degree of risk to regulate the financial leverage.

2) Loss probability $P(X)$ and $\mathrm{D} / \mathrm{A}$

From formula (7), may

$$
\mathrm{E}(\mathrm{ROE})=\frac{1-\mathrm{T}}{1-\mathrm{D} / \mathrm{A}}[\mathrm{E}(\mathrm{ROA})-r \cdot D / A]
$$

Take formula (9) and formula (12) into formula (4), May

$$
\mathrm{X}=\frac{-\frac{1-\mathrm{T}}{1-\mathrm{D} / \mathrm{A}}[\mathrm{E}(\mathrm{ROA})-r \cdot D / A]}{\frac{1-T}{1-D / A} \sigma(R O A)}=\frac{r \cdot D / A-E(R O A)}{\sigma(R O A)}
$$

Then have partial derivative on the $\mathrm{D} / \mathrm{A}$ and $\mathrm{E}(\mathrm{ROA})$ respectively of formula (3), may

$$
\begin{aligned}
& \frac{\partial \Phi(\mathrm{X})}{\partial(\mathrm{D} / \mathrm{A})}=P^{\prime}(\mathrm{X}) \frac{r}{\sigma(R O A)}>0 \\
& \frac{\partial \Phi(X)}{\partial[E(R O A)]}=\frac{-P^{\prime}(X)}{\sigma(R O A)}<0
\end{aligned}
$$

The two formulas show that the probability of loss probability $P(x)$ is an increasing function of assets and liabilities ratio $D / A$, and a decreasing function of the total assets average rate of return $E(R O A)$. It presents that the increase of the debt ratio will increase the probability of lossmaking of a company. But if companies bear a higher rate of total assets return, they can choose a higher debt ratio, because the high return on assets can offset risks brought by debt ratio to some degree.

3) Coefficient $\beta$ and $D / A$

According to formula (5) and (7), there are

$$
\operatorname{COV}\left(R O E, R_{M}\right)=\frac{1-T}{1-D / A} \operatorname{COV}\left(R O A, R_{M}\right)
$$

Take the formula (16) into the formula (5), there are

$$
\beta=\frac{\frac{1-T}{1-D / A} \operatorname{COV}\left(R O A, R_{M}\right)}{\sigma^{2}\left(R_{M}\right)}=\frac{(1-T) \operatorname{COV}\left(R O A, R_{M}\right)}{\sigma^{2}\left(R_{M}\right)(1-D / A)}
$$

Have a partial derivatives of formula (17) for, may

$$
\frac{\partial \beta}{\partial(\mathrm{D} / \mathrm{A})}=\frac{(1-\mathrm{T}) \operatorname{COV}\left(\mathrm{ROA}_{,} \mathrm{R}_{\mathrm{M}}\right)}{\sigma^{2}\left(\mathrm{R}_{\mathrm{M}}\right)(1-\mathrm{D} / \mathrm{A})^{2}}
$$

In the complete market, companies operating situation is synchronized with the changes of market, which means the positive correlation between $R O A$ and $R_{M}$, that is, when $\operatorname{COV}\left(\mathrm{ROA}, \mathrm{R}_{\mathrm{M}}\right)>0$, the formula (18) $>0$, showing that the coefficient $\beta$ is an increasing function of asset-liability ratio, the higher the debt ratio, the greater the coefficient $\beta$ of the enterprise return on equity and the greater risks of the enterprise.

4) Financial leverage $D F L$ and $D / A$

Make formula (6)'s molecular and denominator divided by the total assets $A$, may

$$
\mathrm{DFL}=\frac{\mathrm{ROA}}{\mathrm{ROA}-\mathrm{r} \cdot \mathrm{D} / \mathrm{A}}
$$


Have partial derivatives of $D / A$ and $R O A$ in formula (19) respectively, there are

$$
\begin{aligned}
& \frac{\partial D F L}{\partial(D / A)}=\frac{r \cdot R O A}{(R O A-r \cdot D / A)^{2}}>0 \\
& \frac{\partial D F L}{\partial \mathrm{ROA}}=\frac{-r \cdot D / A}{(R O A-r \cdot D / A)^{2}}<0
\end{aligned}
$$

The Formula (20) and (21) show that financial leverage of assets coefficient $D F L$ is an increasing function of liabilities rate $D / A$, and a decreasing function of the return on total assets. From this we can see that the raise of the debt ratio strengthens the financial leverage, but it also increases the business risks. If enterprises have a high return on total assets, they can properly raise the debt ratio.

According to the data in Table 2, we can make a relationship graph of series measurement indicators $\sigma(R O E)$ of enterprise risk, $\Phi(X)$, factor $\beta$ and $D F L$ assetliability ratio $D / A$. The following four graphs can intuitively reflect the enterprise risk, $D / A$ and $R O A$.
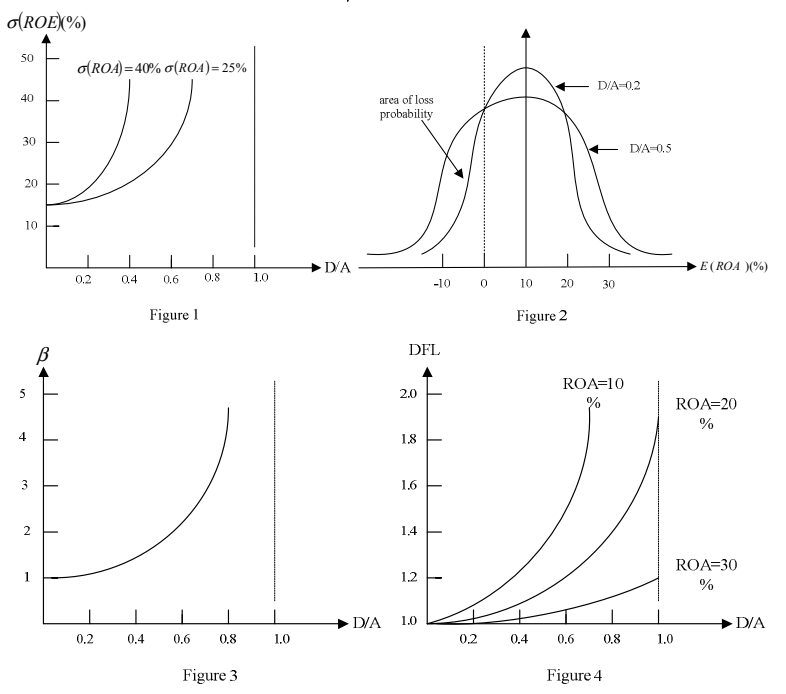

IV. DETERMINATION OF OPTIMAL CAPITAL STRUCTURE

From the above quantitative analysis, we can get the following conclusions: when the business return on total assets (EBIT) is higher than the debt interest rates, raising the debt ratio can improve the return on equity, but at the same time the enterprise risk will also increase. To an enterprise with a higher or comparatively stable Return on total assets, we may properly raise the debt ratio. Thereby we can keep the risk at a certain level then we can take full advantage of financing liabilities of the role of financial leverage as far as possible.

Along with funding benefit from liabilities there is inevitably the increase of risks associated with business. Thus when facing with finance decision-making, an enterprise should choose a capital structure in which the risks match with the additional revenue expected from risk-taking in order to enable enterprises to maximize the stock price.

According to the concept of the capital cost, there are

$$
K=K_{d} \cdot(1-T) \cdot D / A+K_{e} \cdot E / A
$$

Of which: $K$ is the cost of integrated capital, $k_{d}$ is the pre-tax cost of debt capital, $K_{e}$ stands for the cost of equity capital.

The optimized capital structure of an enterprise is one that enables best of the company's overall value. At the same time, under this capital structure, the company's cost of capital is the lowest, that is, to find the best capital structure is essentially to seek the lowest point of the weighted average capital cost.

Usually, since the corporate shareholders assume a higher risk than corporate creditors, they required a higher return rate than creditors. That is to say, the cost of equity capital is higher than the cost of liability capital, so an enterprise can cut down their synthetic capital cost by way of liability funding. However, excessive liabilities funding, whether for the shareholders or creditors will increase their risk, thus they will require a higher return on investment. Therefore the costs of a synthetic enterprise financing capital will gradually decrease to a point with the increase of assets and in the case that the liability is pretty low. Then begin to rise with the continuous increasing of the liabilities ratio. It is the optimal capital structure that the integrated capital costs rising in turn from the drop point.

\section{CONCLUSION}

To sum up, choosing the optimized capital structure for enterprises in the financing decision-making is an important and complex financial management activity. Therefore, in the specific operation process, enterprises should make good use of debt reasonably to improve the effect of financial leverage, so that maximize enterprise value while enable to maintain the cost of capital in a target level of capital structure. Besides, the merit of the capital structure is relative to certain period of a company under certain conditions. During the practice, the company should also analyze the external environment combining with its own characteristics, such as sales growth and its stability sexual, the industry characteristics and socioeconomic environmental conditions, etc., to have a quantitative analysis and qualitative analysis to make their capital structure in the best condition.

\section{REFERENCES}

[1] 1. Milton Harris, Artur Raviv. The theory of capital structure [J]. The Journal of Finance. March1 991 ,XLVI(1 ):297 355

[2] 2. Leland HE. Corporate Debt Value, Bond Covenants, and Optimal Capital Structure [J]. The Journal of Finance, 1 994, 49(4) :874 892

[3] 3. Yang Wenpei, Cui Yuewu: Corporate Financing and Investment, the quantity economic and technical economic research. December, 1997.

[4] 4. Gao Xiaojun, Hao Rong: learn from the western capital structure theory to explore new ideas for fund-raising enterprises, Financial Research. August, 1999. 